\title{
Linfadenite clínica em rebanhos ovinos e caprinos no município de Chapadinha/MA
}

Helder de Moraes Pereira", Diego Moraes Soares, Thais Bastos Rocha, Carlos Henrique Marques Fernandes Marques, Juliana da

Silva Alves, AmandaTaylla Lima Silva

Curso de Medicina Veterinária, Universidade Estadual do Maranhão (UEMA), São Luís, MA, Brasil

*Autor correspondente

e-mail: helderpereirap@yahoo.com.br

\section{Resumo}

A Linfadenite Caseosa, enfermidade crônica causada pelo Corynebacterium pseudotuberculosis, caracterizase pelo aparecimento de abscessos em linfonodos tanto superficiais quanto profundos e em órgãos, acometendo principalmente pequenos ruminantes, sendo responsável por perdas econômicas que ocorrem pela redução na produtividade devido à depreciação da pele, perda de peso e condenação de carcaças, levando a um considerável impacto econômico. Dessa forma, o objetivo do presente trabalho foi conhecer a situação da Linfadenite Caseosa nos seus aspectos clínicos, em pequenos ruminantes no município de Chapadinha/MA, visando o controle da enfermidade para melhorar a exploração econômica e zootécnica dos rebanhos. Foram visitados 13 rebanhos caprinos e três rebanhos ovinos, totalizando 789 caprinos e 204 ovinos em sua maioria sem padrão racial definido (SPRD). Os animais foram avaliados clinicamente por meio de inspeção e palpação dos linfonodos superficiais de cada animal. Dos 13 rebanhos caprinos, 66 animais apresentaram lesão e/ou cicatriz de linfonodos superficiais abecedados. Destes, 41 (5,19\%) apresentaram lesões de Linfadenite Caseosa clínica. Foram descritas 90 lesões em caprinos. 0 linfonodo mais acometido foi o pré-escapular esquerdo com 17 (18,88\%) lesões, seguido pelo submandibular direito com 12 (13,33\%), submandibular esquerdo com 10 (11,11\%), pré-escapular direito com oito (8,88\%), cervical esquerdo com cinco $(5,55 \%)$, cervical direito com três (3,33\%). Em relação aos ovinos, cinco $(2,45 \%)$ apresentaram lesões de Linfadenite clínica. Quanto ao rebanho de ovinos encontramos cinco lesões no total, sendo o linfonodo pré-escapular esquerdo com duas (40\%) lesões, submandibular direito e esquerdo com uma (20\%) lesão e pré-escapular direito também com uma lesão (20\%). Estes dados mostram de forma clara falhas no manejo sanitário destes animais. 0 próprio sistema de criação empregado nestes rebanhos, o extensivo, propicia a facilidade da transmissão desta enfermidade. No nordeste brasileiro a linfadenite caseosa é uma enfermidade endêmica e de difícil controle nestes rebanhos. Assim, pode-se concluir que a frequência da 
Linfadenite Caseosa clínica em rebanhos caprinos e ovinos do Município de Chapadinha é baixa, e que o manejo sanitário destes animais é deficiente, apresentando sérios problemas que podem interferir no desempenho destes rebanhos, necessitando adequações visando à maximização da produtividade. 